\title{
MODEL PENYELESAIAN SENGKETA EKONOMI SYARIAH YANG EFEKTIF DIKAITKAN DENGAN KOMPETENSI DI PERADILAN AGAMA DALAM RANGKA PERTUMBUHAN EKONOMI NASIONAL
}

\author{
Renny Supriyatni ${ }^{1}$ dan Andi Fariana ${ }^{2}$ \\ ${ }^{1}$ Fakultas Hukum Universitas Padjadjaran, Bandung \\ renibachro@ymail.com \\ ${ }^{2}$ Dosen Tetap FEB ABFII Perbanas (Perbanas Institute), Jakarta \\ afariana@yahoo.com
}

\begin{abstract}
Abstrak
$\mathrm{P}$ enyelesaian sengketa ekonomi syariah yang efektif (win win solution) merupakan suatu keniscayaan dalam setiap aktifitas bisnis. Semakin berkembang ekonomi syariah dan aktifitas bisnis maka kemungkinan jumlah sengketapun akan meningkat. Berkembangnya ekonomi dan bisnis yang didasarkan prinsip syariah menyebabkan jenisjenis sengketa juga semakin beragam baik pola dan jenisnya. Pengadilan Agama sebagai lembaga litigasi yang memiliki kewenangan absolut dalam menyelesaikan sengketa ekonomi syariah menjadi perhatian mengingat selama ini dikenal sebagai lembaga litigasi yang hanya menyelesaikan sengketa dalam bidang hukum keluarga. Permasalahan yang muncul, bagaimana modelnya dikaitkan dengan kompetensi Pengadilan Agama. Penelitian ini bertujuan menemukan model sebagai solusi mengenai penyelesaian sengketa ekonomi syariah yang efektif di Pengadilan Agama dalam rangka mendukung pertumbuhan ekonomi nasional.

Metode penelitian yang digunakan, secara yuridis normatif, dengan pendekatan deskriftif analitis, yaitu menggambarkan secara sistematis, faktual dan akurat, segala fakta dan permasalahan yang diteliti dikaitkan dengan teori-teori hukum dan praktik. Selanjutnya, data yang diperoleh dianalisis secara yuridis kualitatif. yang merupakan suatu metode untuk menganalisis data dengan mempergunakan perundang-undangan yang berlaku dan antara satu dengan yang lainnya tidak boleh saling bertentangan, memperhatikan khierarkhi dengan tujuan untuk mewujudkan kepastian hukum, serta melaksanakan amanat Undang-Undang Kekuasaan Kehakiman yang menyatakan bahwa hakim wajib mencari dan menggali hukum yang hidup di dalam masyarakat, atau lebih dikenal dengan "the living law", baik itu yang tertulis maupun tidak tertulis (Hukum Islam).

Hasil penelitian menunjukkan bahwa, penyelesaian sengketa yang cepat, murah, transparan, adil serta menjamin kepastian hukum menjadi tolok ukur bagi para investor. Oleh karena itu, menjadi penting keberadaan Peradilan Agama untuk menerapkan model mediasi di dalam Pengadilan yang ditangani oleh mediator-mediator independent bersertifikat dan berstatus hakim yang memiliki kompetensi absolut, serta didukung oleh putusan yang memiliki kepastian dan kekuatan hukum mengikat. Saran diajukan, dibentuk Peradilan Niaga Syariah Adhoc yang akan menerapkan proses mediasi syariah untuk menyelesaikan sengketa ekonomi syariah, sehingga pada akhirnya akan lahir kepercayaan yang tinggi terhadap proses penyelesaian sengketa di Pengadilan Agama. Hal tersebut, akan berdampak positif, diantaranya kepercayaan investor untuk berinvestasi dalam bidang bisnis syariah meningkat, dan secara tidak langsung memberikan kontribusi positif terhadap meningkatnya pertumbuhan ekonomi nasional.
\end{abstract}

Kata Kunci: Peradilan Agama, Mediasi, Peradilan Niaga Adhoc, dan Ekonomi Nasional. 


\begin{abstract}
$E$ ffective Syariah Economy Dispute Settlement (Win win solution) is important in every business activities. The growing Syariah Economy and business activities causes the number of dispute to increase. The growth of economy and businesses that are based on Syariah principles creates a variety of disputes. Religious court as a litigation constitution that has the absolute authority to settle Syariah economy disputes, has been a center of attention because it is known as the litigation constitution that only settle disputes regarding family laws. This research aimed to find a model as a solution for an effective Syariah economy dispute settlement in the religious court to support the growth of the national econonmy.

The research method that are used are based on juridical and normative, with analytical descriptive approach, by describing systematically, factual and accurate. All kind of facts and problems that are being researched are correlated with law theories and practice. Data that are obtained are analyzed through juridical qualitative. This is a method to analyze data by utilizing the applicable laws and each law cannot be conflicted with another, concerning the hierarchy with the purpose to realize legal certainty as well as implement the mandate of judge authority law that specified that a judge has the obligation to search and dig the living law in the community, or known as "the living law", whether it is written or not (Hukum Islam).

The research result shows that a quick, cheap, transparent, fair dispute settlement becomes a benchmark by the investors. Therefore, the existence of religious court has become very important to apply the mediation model in the courts that are handled by the certified independent mediators and with the title of judge with absolute competency, as well as supported by the decision that has certainty and binding law. It is suggested to form an Adhoc Commerce Syariah Court that able to implement the Syariah mediation process to settle syariah economy dispute, so that in the end will emerge higher faith to the dispute settlement process in the religious court. This will have positive impacts, one of the example is that the investor's trust to invest in syariah business will increase and indirectly give positive contribution to the growth of national economy.
\end{abstract}

Keywords: Religious court, Mediation, Adhoc Commerce Court, and National Economy

\title{
Pendahuluan
}

Sistem ekonomi internasional dimana perbankan merupakan subsistem terpenting, demikian juga halnya dengan sistem ekonomi nasional. Selain itu, penduduk muslim yang besar dapat menjadi potensi nasabah industri keuangan syariah dan dapat mendukung terciptanya kondisi ekonomi yang cerah, serta ditopang oleh sumber daya alam melimpah yang dapat dijadikan sebagai underlying transaksi industri keuangan syariah. ${ }^{124}$ Dalam melakukan aktivitas ekonomi, ${ }^{125} 2$ manusia sebagai anggota masyarakat memerlukan suatu pola atau aturan yang sama dengan anggota masyarakat di wilayah lainnya. Hal ini diperlukan untuk memberikan suatu kemudahan dan keadilan dalam bertransaksi, biasanya dilandasi atas pengetahuan dan tradisi setempat serta adanya dari kesepakatan kedua belah pihak.

Kebutuhan terhadap suatu hukum yang mengatur dan memelihara hubungan masyarakat, bermanfaat untuk kepentingan bersama. Pengetahuan akan suatu aturan atau hukum didapatkan dengan bagaimana manusia dapat menelaah sesuatu dengan akal pikirannya baik diilhami oleh kejadian-kejadian alam ataupun ilmu yang terdapat dalam kitab suci suatu agama (ajaran Islam). ${ }^{126} 3$ Hal tersebut sejalan dengan Pembukaan UUD 1945 Alinea Ketiga yang menyatakan 124 Halim Alamsyah (Deputi Gubernur BI), Loccit.

$125{ }^{2}$ Muhammad Nejatullah Siddiqi, "Teaching Islamic Economics", Scientific Publishing Centre- King Abdulaziz University (Jeddah, Saudi Arabia, 2005), 6-7.

$126{ }^{3}$ Renny Supriyatni B, Pengantar Perbankan Syariah Di Indonesia, Books Terrace \& Library, Bandung, 2013, hlm. 1-3. Dikutip dari Muhammad Nejatullah Siddiqi, Loccit. Mohon lihat pula, Frank E. Vogel \& 
"Atas berkat rahmat Allah Yang Maha Kuasa..." serta pada Alinea Keempat yang merupakan dasar negara Republik Indonesia yaitu Sila Pertama Pancasila; "Ketuhanan yang Maha Esa". Hal ini menunjukkan bahwa bangsa Indonesia adalah masyarakat yang religius, yang begitu kental dengan nilai-nilai ke-Tuhanan dan pengakuan akan adanya suatu hukum positif yang berasal dari Tuhan.

Selanjutnya Pembangunan Nasional bertujuan untuk mewujudkan masyarakat adil dan makmur yang merata material dan spiritual berdasarkan Pancasila dan Undang-undang Dasar 1945 dalam wadah negara Kesatuan Republik Indonesia yang merdeka, berdaulat, bersatu, dan berkedaulatan rakyat dalam suasana perikehidupan bangsa yang aman, tenteram, tertib, dan dinamis dalam lingkungan pergaulan dunia yang merdeka, bersahabat, tertib dan damai. Ketentuan Pasal 33 UUD 1945 (Amandemen IV), menggariskan bahwa:

1. Perekonomian disusun sebagai usaha bersama berdasar atas asas kekeluargaan;

2. Produksi yang penting bagi negara dan yang menguasai hajat hidup orang banyak dikuasai oleh negara;

3. Bumi, air dan kekayaan alam yang terkandung didalamnya dikuasai oleh negara dan dipergunakan untuk sebesar-besar kemakmuran rakyat;

4. Perekonomian nasional diselenggarakan berdasar atas demokrasi ekonomi dengan prinsip kebersamaan, efisiensi berkeadilan, berkelanjutan, berwawasan lingkungan, kemandirian, serta dengan menjaga keseimbangan kemajuan dan kesatuan ekonomi nasional.

Hal tersebut di atas, tersimpul tugas konstitusional bahwa perekonomian harus disusun, bukan dibiarkan dengan sendirinya tersusun dan berkembang tanpa susunan. Sistem pengaturan ekonomi dan atau perijinan perlu berperan demikian rupa, dengan sadar dan aktif menyusun perekonomian nasional, membentukan sistem kebersamaan dan kekeluargaan dalam setiap mengatur dan mengeluarkan ijin di dalam kehidupan ekonomi. Dengan kata lain, setiap ijin usaha dan ijin-ijin lain yang berkaitan dengan itu harus menjamin penerima ijin terikat untuk melaksanakan sistem kebersamaan dan kekeluargaan. Tujuan tersebut tercapai, setelah dilaksanakan pembangunan di segala bidang secara bersama oleh masyarakat dan pemerintah, dengan titik berat diletakkan pada bidang ekonomi seiring dengan kualitas sumberdaya manusia tetap bertumpu pada aspek pemerataan, pertumbuhan dan stabilitas. Sehubungan dengan masalah perekonomian, salah satu tujuan dari pembangunan adalah mencapai cita-cita bangsa yaitu terciptanya masyarakat adil dan makmur. Masyarakat adil makmur yang dimaksud adalah merupakan tujuan dari pembangunan ekonomi Indonesia yang didasarkan atas Demokrasi Ekonomi. ${ }^{127} 4$

Selanjutnya pertumbuhan perbankan syariah di Indonesia berkembang dengan pesat, ${ }^{128} 5$ merupakan hal positif dan turut pula tumbuh dan berkembang unit usaha syariah pada Bank konvensional yang kesemuanya secara simultan memberi dampak bagi tumbuhnya berbagai kegiatan dalam bidang ekonomi syariah. Khususnya keuangan yang bernuansa syariah seperti lahirnya asosiasi dan organisasi sebagai lembaga keuangan syariah, yakni asuransi, Baitul Muttanwil (BMT), penjaminan, pegadaian, juga lahirnya aktifitas bisnis berbasis syariah seperti hotel, MLM, IT, pendidikan dan layanan hukum seperti arbitrase dan peradilan. ${ }^{129} 6$ Secara umum pertumbuhan aspek-aspek bisnis ini masuk kedalam sistem ekonomi syariah. Pertumbuhan kegiatan bisnis yang bernuansa syariah tersebut, tentu akan diikuti berbagai

Samuel L. Hayes, III (Penterjemah: M. Sobirin Asnawi at. al.), "Hukum Keuangan Islam, Konsep, Teori dan Praktek (Islamic Law and Finance: Religion, Risk, and Return)”, Cet. I, Nusamedia, Bandung, 2007, hlm. 23.

$127{ }^{4}$ Renny Supriyatni B, Loccit. Sejalan dengan Pasal 2 Undang-undang Perbankan Syariah (UUPS) dan Penjelasannya, yang dimaksud Demokrasi Ekonomi adalah kegiatan ekonomi syariah yang mengandung nilai keadilan, kebersamaan, pemerataan, dan kemanfaatan.

$128{ }^{5}$ Yuslam Fauzi, Seminar Nasional Ekonomi Syariah, ABFII Perbanas, Jakarta, 20 Februari 2013

$129{ }^{6}$ Yuslam Fauzi, op.cit 
persoalan dan hal ini menjadi potensi kemungkinan terjadinya sengketa.

Penyelesaian sengketa dalam bidang bisnis menurut Hukum Islam bisa dilakukan dengan dua cara yaitu secara litigasi di Pengadilan dan secara Non Litigasi yaitu dengan model mediasi syariah (ash shulhu) ataupun arbitrase (at tahkim) yaitu antara lain melalui Basyarnas (Badan Arbitrase Syariah Nasional). ${ }^{130} 7$ Penyelesaian sengketa secara litigasi terjadi, sejak dikeluarkannya Putusan Mahkamah Konstitusi Nomor 93/PUU-X/2012 memberikan kewenangan mutlak kepada Peradilan Agama. Hal tersebut berkaitan dengan penyelesaian sengketa ekonomi syariah secara litigasi di Pengadilan Agama, perlu dikaji secara mendalam tentang kompetensi Peradilan Agama dan model penyelesaian sengketa yang efektif, mengingat selama ini Peradilan Agama merupakan lembaga litigasi yang hanya menyelesaikan sengketasengketa dalam bidang hukum keluarga, sementara pertumbuhan bisnis syariah memiliki kompleksitas yang tinggi seiring dengan pertumbuhannya yang pesat. Penelitian ini dilakukan untuk menjawab permasalahan, bagaimanakah kompetensi dan model penyelesaian sengketa ekonomi syariah yang efektif di Pengadilan Agama dalam rangka mendukung pertumbuhan ekonomi nasional.

\section{Metode penelitian}

Penelitian ini merupakan penelitian hukum normatif (yuridis normatif) yang menitikberatkan pada penelitian terhadap asas dan kaidah hukum berupa sinkronisasi horizontal dan vertical. ${ }^{131} 8$ Guna menjawab secara tepat pertanyaan di dalam identifikasi masalah, maka akan dilakukan kajian dengan beberapa pendekatan yaitu: (1) pendekatan perundangundangan (statute approach), (2) pendekatan sejarah (hystorical approach), (3) Pendekatan politis (Political approach). Data yang sudah dikumpulkan, dilakukan analisis secara yuridis kualitatif yang merupakan suatu metode mempergunakan perundang-undangan yang berlaku. Langkah-langkahnya antara lain: Peraturan perundang-undangan antara satu dengan peraturan perundang-undangan yang lainnya tidak boleh saling bertentangan, memperhatikan khierarkhi dengan tujuan untuk mewujudkan kepastian hukum, dan melaksanakan amanat UndangUndang Kekuasaan Kehakiman yang menyatakan bahwa hakim wajib mencari dan menggali hukum yang hidup di dalam masyarakat, atau lebih dikenal dengan "the living law", baik itu yang tertulis maupun tidak tertulis (Hukum Islam). Selanjutnya, dilakukan intrepretasi untuk mendapatkan kesimpulan.

\section{Pembahasan}

\section{Negara Pancasila sebagai wadah percepatan pertumbuhan ekonomi syariah}

Indonesia menganut konsep Negara Hukum Pancasila yang berbeda dengan konsep barat pada umumnya. Beberapa ciri dari Negara Hukum Pancasila: (1) Ada hubungan yang erat antara agama dan Negara. (2) Negara dan Hukum bertumpu pada Ketuhanan Yang Maha Esa. (3) Ada jaminan kebebasan beragama dalam arti positif. (4) Ateisme tidak dibenarkan dan komunisme dilarang. (5) ditetapkannya asas kekeluargaan dan kerukunan. Menurut M. Tahir Azhari, Indonesia tergolong sebagai Negara Nomokrasi yaitu Negara yang kekuasaannya di dasarkan pada hukum-hukum dari Tuhan. ${ }^{132} 9$ Dua hal yang perlu diperhatikan dalam Negara Hukum Pancasila. Pertama, adanya kebebasan beragama yang harus mengacu pada makna yang positif sehingga pengingkaran terhadap Tuhan Yang Maha Esa (atheisme) ataupun sikap

$130 \quad{ }^{7}$ Yudo Paripurno, Peran Basyarnas dalam penyelesaian sengketa ekonomi syariah, http://examinasi. com/2012/01, (diakses pada 02 Maret 2012)

$131{ }^{8}$ Soerjono Soekanto, Penelitian Hukum Normatif (Jakarta: Raja Grafindo persada, cetakan 14, juni 2012), 14 dan 52.

$132{ }^{9}$ Muhammad Tahir Azhari, Negara Hukum Suatu Studi tentang Prinsip Prinsipnya Dilihat Dari Segi Hukum Islam, Implementasinya pada Periode Negara Madinah dan Masa Kini (Jakarta: Bulan Bintang, 1992), 71-72. 
yang memusuhi Tuhan Yang Maha Esa dilarang. Kedua, ada hubungan yang erat antara agama dan Negara, karena itu baik secara kaku (rigid) (mutlak) maupun secara longgar (nisbi) Negara Republik Indonesia tidak mengenal doktrin pemisahan antara agama dan Negara karena doktrin pemisahan antara agama dengan Negara sangat bertentangan dengan Pancasila dan UUD $1945 .{ }^{133} 10$

Menurut A.Hasjmy, agama dan Negara memiliki hubungan yang bersifat simbiotik, dimana antara keduanya mempunyai hubungan timbal balik yang saling melengkapi dan menguntungkan. ${ }^{134} 11$ Selanjutnya menurut A. Hasjmy, dengan melaksanakan prinsip-prinsip Pancasila berarti sekaligus melaksanakan prinsip-prinsip Islam. Oleh sebab itu, A Hasjmy dapat menerima konsep Negara bangsa (nation state) tanpa harus menyebut Negara Islam. ${ }^{135} 12$ Pemikiran inilah yang menjadi dasar keyakinan bahwa pertumbuhan ekonomi syariah akan terus tumbuh dengan cepat dan sistem penyelesaian sengketa secara syariah harus terus diperkuat.

\section{Kompetensi dan Model penyelesaian sengketa ekonomi syariah yang efektif di Peradilan Agama dalam rangka mendukung pertumbuhan ekonomi Nasional}

Perjalanan panjang Peradilan Agama di Indonesia mengalami pasang surut lingkup kewenangan dan wilayah kewenangannya dengan berbagai peraturan perundang-undangan yang menjadi dasarnya, Bahkan keberadaan Peradilan Agama sebagai lembaga litigasi yang otonom juga mengalami berbagai perubahan dalam koordinasinya. Berikut matrik yang menunjukkan hal tersebut.

Undang Undang Mahkamah Agung yang menyatakan Peradilan Agama berada dibawah Kekuasaan Mahkamah Agung

\begin{tabular}{|c|l|l|}
\hline No & \multicolumn{1}{|c|}{ Undang Undang Mahkamah Agung } & \multicolumn{1}{c|}{ Undang Undang Peradilan Agama } \\
\hline 1 & $\begin{array}{l}\text { Undang Undang No. 19 Tahun 1948 tentang } \\
\text { susunan dan kekuasaan badan-badan } \\
\text { Kehakiman dan Kejaksaan, }\end{array}$ & $\begin{array}{l}\text { Peradilan Agama berada dibawah Departemen } \\
\text { Agama }\end{array}$ \\
\hline 2 & $\begin{array}{l}\text { Undang Undang Nomor 19 Tahun 1964 } \\
\text { tentang Ketentuan- ketentuan Pokok } \\
\text { Kekuasaan kehakiman. }\end{array}$ & $\begin{array}{l}\text { Peradilan Agama berada dibawah Departemen } \\
\text { Agama }\end{array}$ \\
\hline 3 & $\begin{array}{l}\text { Undang Nomor 14 Tahun 1974 tentang } \\
\text { Kekuasaan Kehakiman }\end{array}$ & $\begin{array}{l}\text { Peradilan Agama berada dibawah Departemen } \\
\text { Agama }\end{array}$ \\
\hline 4 & $\begin{array}{l}\text { Undang Undang Nomor 35 Tahun 1999 } \\
\text { Nontang Perubahan atas Undang Undang } \\
\text { ketentuan Pokok Kekuasaan Kehakiman, }\end{array}$ & $\begin{array}{l}\text { Peradilan Agama berada dibawah Mahkamah } \\
\text { Agung }\end{array}$ \\
\hline 5 & $\begin{array}{l}\text { Undang Undang Nomor 4 Tahun 2004 } \\
\text { tentang Kekuasaan Kehakiman }\end{array}$ & $\begin{array}{l}\text { Peradilan Agama berada dibawah Mahkamah } \\
\text { Agung }\end{array}$ \\
\hline Kndang Undang No. 48 Tahun 2009 tentang \\
Kekuasaan Kehakiman
\end{tabular}

Selain persoalan koordinasi sebagaimana matrik di atas, kewenangan Peradilan Agama didalam menyelesaikan sengketapun mengalami perubahan-perubahan namun secara umum yang tidak pernah lepas dari kewenangan Peradilan Agama adalah kewenangan dalam hal menyelesaikan sengketa dalam bidang hukum keluarga. Saat ini, berdasarkan Undang-undang

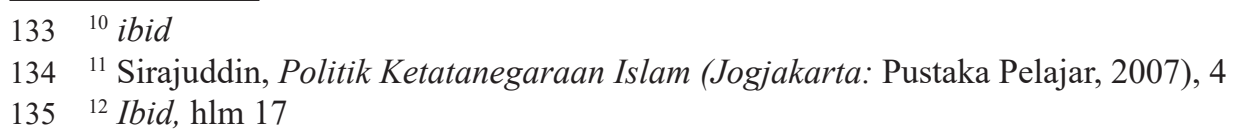


Nomor 3 Tahun 2006 Tentang Amandemen Undang-undang Nomor 7 Tahun 1989 Tentang Peradilan Agama Juncto Undang-undang Nomor 50 Tahun 2009 Tentang Perubahan Undangundang Nomor 7 Tahun 1989 Tentang Peradilan Agama, kewenangan Peradilan Agama ditambah yaitu untuk menyelesaikan sengketa Ekonomi Syariah. Kemudian terjadi choice of Law dan Choice of forum dalam hal penyelesaian sengketa ekonomi syariah yaitu dengan keluarnya UU Nomor 21 Tahun 2008 Tentang Perbankan Syariah, yang menyebutkan didalam Penjelasan Pasal 55 ayat (2) bahwa penyelesaian sengketa ekonomi syariah dapat dilakukan melalui musyawarah, mediasi, Peradilan Umum dan Peradilan Agama. Sehingga hal tersebut menyebabkan munculnya Yudicial Review terhadap Pasal 55 ayat (2), dan akhirnya keluarlah Keputusan Mahkamah Agung Nomor 93/PUU-X/2012 yang menyatakan kewenangan absolut menyelesaikan sengketa ekonomi syariah berada pada Pengadilan Agama.

Dalam Kompetensi absolut Pengadilan Agama untuk menyelesaikan sengketa ekonomi syariah, memiliki beberapa keunggulan dan kendala tersendiri. Beberapa keunggulan dan kekurangan Peradilan Agama dalam menyelesaikan sengketa ekonomi syariah, apabila dibandingkan dengan Badan Arbitrase Syariah Nasional (selanjutya ditulis Basyarnas) diuraikan sebagai berikut. Keunggulannya ${ }^{136} 13$ yaitu: Pertama, Pengadilan Agama memiliki Sumber Daya Insani yang sudah memahami permasalahan syariah, tinggal meningkatkan wawasan dan pengetahuan mereka melalui pendidikan dan pelatihan secara berkala. Kedua, Peradilan Agama memiliki hukum materiil yang cukup memadai, khususnya yang berkaitan dengan ekonomi syariah, diantaranya berupa kitab-kitab fikih muamalah yang dalam penerapannya masih kontekstual. Ketiga, Keberadaan kantor Pengadilan Agama hampir meliputi semua wilayah kabupaten dan kotamadya di seluruh wilayah Indonesia. Sebagian besar telah mengaplikasikan jaringan tekhnologi informasi berbasis internet, sehingga apabila dibandingkan dengan Basyarnas yang yang keberadaannya masih terkonsentrasi di wilayah ibukota, maka Peradilan Agama mempunyai keunggulan dalam kemudahan pelayanan. Keempat, mendapat dukungan mayoritas penduduk Indonesia, yaitu masyarakat muslim yang saat ini sedang memiliki semangat yang tinggi dalam menegakkan nilai-nilai agama yang mereka anut. Kelima, Adanya dukungan politis yang kuat karena Pemerintah dan Dewan Perwakilan Rakyat (DPR) telah menyepakati perluasan kewenangan Peradilan Agama pada Tanggal 21 Februari 2006 sehingga lahir UUPA No. 3 Tahun 2006 yang merupakan keniscayaan dalam memenuhi tuntutan hukum yang ada, yaitu perubahan paradigma dari peradilan keluarga menuju peradilan modern. Keenam, Adanya dukungan dari otoritas perbankan (Bank Indonesia) dan dukungan dari lembaga keuangan Islam di seluruh dunia.

Disamping keunggulan-keunggulannya, maka berikut beberapa kekurangan ${ }^{137} 14$ Peradilan Agama di dalam menjalani perannya sebagai lembaga litigasi yang berwenang menyelesaikan sengketa ekonomi syariah. Pertama, Belum ada regulasi atau peraturan perundang-undangan yang secara spesifik (masih dalam bentuk Peraturan Mahkamah Agung, yakni PERMA nomor 2 Tahun 2008 Tentang Kompilasi Ekonomi Syariah) yang mengatur tentang ekonomi syariah. Sehingga dengan adanya beberapa rujukan kitab hukum, akan dimungkinkan munculnya disparitas putusan dalam kasus yang sama. Hal ini bukan saja dapat membingungkan umat, tetapi juga tidak menguntungkan dalam dunia bisnis sehingga dikhawatirkan sikap trauma bagi para pelaku ekonomi syariah untuk berperkara di Pengadilan Agama. Kedua, Aparat Peradilan Agama yang sebagian besar memiliki latar belakang pendidikan syariah dan hukum kurang memahami aktifitas ekonomi baik yang bersifat makro maupun mikro, juga bidang usaha sektor riil, produksi, distribusi dan konsumsi. Sebagai tambahan kelemahannya, Ketiga, Hakim-hakim dan Aparat Peradilan Agama yang sebagian besar memiliki latar belakang pendidikan syariah dan hukum kurang memahami hukum acaranya.

\footnotetext{
$136{ }^{13}$ Hasbi Hasan, Kompetensi Peradilan Agama (dalam penyelesaian sengketa ekonomi syariah), (Depok: Gramata Publishing, 2010), 188-189.

$137{ }^{14}$ Hasbi Hasan, Ibid, hlm. 189-190
} 
Matrik yang menunjukkan sejarah kewenangan Peradilan Agama di dalam menyelesaikan sengketa ekonomi syariah, sebagai berikut:

Undang Undang Peradilan Agama yang menambah kewenangan Peradilan Agama untuk menyelesaik
sengketa ekonomi syariah
\begin{tabular}{|c|l|l|}
\hline No & Undang Undang Peradilan Agama & \multicolumn{1}{|c|}{ Keterangan } \\
\hline 1 & $\begin{array}{l}\text { Undang Undang No 7 Tahun 1989 } \\
\text { Tentang Peradilan Agama }\end{array}$ & $\begin{array}{l}\text { Sengketa ekonomi syariah belum menjadi } \\
\text { kewenangan Peradilan Agama }\end{array}$ \\
\hline 2 & $\begin{array}{l}\text { Undang Undang No. 3 Tahun 2006 } \\
\text { tentang Peradilan Agama }\end{array}$ & $\begin{array}{l}\text { Pada Pasal 49 memperluas kewenangan } \\
\text { Peradilan Agama untuk juga menyelesaikan } \\
\text { sengketa dalam bidang ekonomi Syariah }\end{array}$ \\
\hline 3 & $\begin{array}{l}\text { Undang Undang No. 50 Tahun 2009 } \\
\text { Tentang Perubahan Kedua atas Undang } \\
\text { Undang Nomor 7 Tahun 1989 Tentang } \\
\text { Peradilan Agama }\end{array}$ & $\begin{array}{l}\text { Memperkuat perluasan kewenangan Peradilan } \\
\text { Agama untuk menyelesaikan sengketa ekonomi } \\
\text { syariah }\end{array}$ \\
\hline
\end{tabular}

Penetapan Peradilan Agama dibawah Mahkamah Agung memberikan isyarat pentingnya untuk dilakukan pembinaan secara lebih utuh menyeluruh dan terpadu sehingga pengembangannya juga lebih terarah. Semua itu tentu saja bertujuan untuk memberikan pelayanan, penegakkan hukum, kepastian hukum serta terpenuhinya rasa keadilan bagi warga Negara Indonesia khususnya umat Islam yang mencari keadilan. Pembinaan sebagaimana dimaksud juga bertujuan agar Peradilan Agama memiliki kemampuan dalam menjalankan tugas dan fungsi sebagaimana yang telah diberikan oleh peraturan perundang undangan. Pembinaan yang terpadu antara Mahkamah Agung, Departemen Agama dan Departemen Kehakiman diharapkan dapat mewujudkan semua tujuan tersebut. Sebagai salah satu contoh langkah nyata di dalam pembinaan terpadu, telah diterbitkan SKB tanggal 25 Februari 1988 Nomor KMA/010/SKB/II/1988, M-01 PR.0802 Tahun 1988 dan Nomor 30/1988 Tentang Pengawasan Hakim Peradilan Agama, dilanjutkan dengan berbagai bentuk kerjasama lainnya untuk mendorong percepatan dicapainya tujuan tersebut. ${ }^{138} 15 \quad$ Bahkan setelah keluarnya Undang Undang Nomor 3 Tahun 2006 tentang Peradilan Agama, Mahkamah Agung melakukan berbagai terobosan dalam rangka melakukan pembinaan untuk memaksimalkan tugas dan fungsi Peradilan Agama. Mahkamah Agung di dalam melakukan pembinaan dititikberatkan pada pembinaan hakim yaitu agar ada perubahan terhadap pemahaman syariah dan fiqih. Mengubah cara berfikir hakim dan metodologi yang dipergunakan sehingga pemahaman dan penerapannya benar-benar tepat dalam rangka mengemban kekuasaan kehakiman sebagaimana diharapkan.

Undang Undang Nomor 49 Tahun 2009 Tentang Mahkamah Agung yang menentukan agar semua lembaga peradilan segera bergabung menjadi satu atap di Mahkamah Agung, kemudian diperkuat dengan Undang Undang Nomor 48 Tahun 2009 Tentang Kekuasaan Kehakiman, menyebabkan Kekuasaan Kehakiman sejajar dengan lembaga peradilan lain, sementara Undang Undang Nomor 7 Tahun 1989 tentang Peradilan Agama yang direvisi dengan Undang Undang Nomor 3 Tahun 2006 serta kembali direvisi dengan Undang Undang Nomor 50 Tahun 2009 memberi kewenangan Peradilan Agama yang lebih luas. Semua Undang Undang tersebut memberi konsekuensi bagi Pengadilan Agama baik dalam bidang pembinaan, kepengurusannya, dan pelaksanaan tugas wewenangnya. Hal tersebut, sesuai dengan yang disampaikan oleh Andi Syamsu Alam, ${ }^{139} 16$ bahwa kebijakan satu atap selain ditujukan untuk menciptakan $138{ }^{15}$ Abdul Manan, op.cit., hlm 219

$139{ }^{16}$ Andi Syamsu Alam (Ketua Muda Mahkamah Agung Urusan LIngkungan Peradilan Agama) dalam kata Pengantar Buku Hasbi Hasan, berjudul Kompetensi Peradilan Agama (Gramata publishing, 2010), xix-xx 
kekuasaan yang independen dan lepas dari kekuasaan lainnya, juga memiliki implikasi khusus terhadap Pengadilan Agama yaitu: Pertama, hal-hal yang menyangkut pengelolaan organisasi, administrasi, dan keuangan telah beralih dari Departemen Agama ke Mahkamah Agung. Kedua, perubahan kedudukan Direktorat Peradilan Agama menjadi Direktorat dan Pengembangan Peradilan Agama (ini memberi keleluasaan bagi pembangunan dan pengembangan Peradilan Agama). Ketiga, perubahan sistem penerimaan calon Hakim. Selain dinamika yang terjadi maka harus diimbangi pula dengan kesiapan SDM dari hakim-hakim di lingkungan Peradilan Agama agar dapat memberikan rasa keadilan bagi pencari keadilan dan menjadi faktor tumbuh kembangnya perekonomian bangsa ke arah yang lebih baik. Hakim Peradilan Agama dituntut untuk menguasai lebih dalam mengenai seluk beluk perbankan, asuransi, reasuransi, reksadana, pasar modal dan sebagainya serta berbagai peraturan perundangannya.

Bagir Manan ${ }^{140} 17$ mencatat beberapa strategi yang harus dilakukan oleh Peradilan Agama dalam rangka pengembangan dan pembinaan, walaupun disampaikan pada Tahun 1989 rasanya masih cukup relevan untuk saat ini, sebagai berikut.

1. Pengembangan dan pembinaan organisasi baik organisasi yustisial dan nonyustisial;

2. Pengembangan dan pembinaan ketenagaan yang meliputi hakim dan non-hakim, mulai dari sistem pendidikan, rekrutmen, promosi, dan sebagainya

3. Pembinaan dan pengembangan tatacara beracara, tatatertib persidangan, dan sebagainya;

4. Pengembangan dan pembinaan tata kerja pelayanan administrasi yang efektif dan efisien;

5. Pengembangan dan pembinaan satuan fasilitas seperti kantor, peralatan, kepustakaan, dan sebagainya

6. Pengembangan dan pembinaan integritas serta disiplin seperti sistem pemindahan terhadap hakim-hakim yang tidak menunjukkkan integritas dan kecakapan melaksanakan kekuasaan kehakiman sebagai tempat mewujudkan keadilan dan kebenaran.

Semua bentuk pembinaan sebagaimana dikemukakan di atas nampaknya telah termuat di dalam rencana Induk Pengembangan Peradilan Agama Jangka Panjang Pertama (RIPPA I) Tahun 1996-2021 yang dibuat oleh Direktorat Pembinaan Peradilan Agama Departemen Agama RI. ${ }^{141} 18$

Sebagai pendukung upaya pembinaan, perlu pula dicari terobosan atau peluang lain agar upaya mencari keadilan dalam menyelesaikan sengketa ekonomi syariah dirasakan maksimal oleh pencari keadilan. Salah satu hal yang harus ditinjau dan dijadikan pertimbangan adalah memaksimalkan forum mediasi di Pengadilan Agama. Diketahui bahwa mediasi dapat dilakukan di dalam pengadilan dan diluar pengadilan. Jika mediasi dilakukan diluar pengadilan berarti itu dilakukan oleh lembaga-lembaga mediasi yang ada, sedangkan mediasi di dalam pengadilan berarti mediasi tersebut merupakan bagian dari proses peradilan. Pada 11 September 2003, Ketua Mahkamah Agung mengeluarkan Peraturan Mahkamah Agung No. 02 Tahun 2003 (diperbaharui dengan Perma No. 1 Tahun 2008) Tentang Prosedur Mediasi di Pengadilan. Perma ini mengharuskan semua sengketa perdata untuk diselesaikan melalui mediasi terlebih dahulu sebelum masuk ke Pengadilan.

Penggunaan prosedur mediasi melalui pengadilan (litigasi) adalah wajib dan dalam hal ini dimungkinkan karena hukum acara perdata yang berlaku di Indonesia, yakni Hierziening Indiche Reglement (selanjutnya ditulis HIR dan RBG) menentukan bahwa hakim diwajibkan untuk terlebih dahulu mengupayakan proses perdamaian. Berlakunya PERMA tentang kewajiban mediasi ini menjadikan mediasi sebagai bagian dari proses beracara pada pengadilan, dan menjadi bagian integral dalam penyelesaian sengketa di pengadilan. ${ }^{142} 19$ Pengintegrasian

$140{ }^{17}$ Bagir Manan, Strategi Pengembangan Peradilan Agama, (Makalah dalam seminar tentang Peradilan Agama PPHIM \& Departemen Agama, Jakarta tanggal 8 Desember 1989), 4-5

$141{ }^{18}$ Abdul Manan, op.cit., hlm. 227

$142{ }^{19}$ Hasil penelitian Sdr. Sufiarina dalam disertasi doktoral di FH Unpad, 2014. Renny Supriyatni, op.cit., hlm 80-84. 
mediasi kedalam proses beracara di pengadilan dapat menjadi salah satu instrumen yang cukup efektif dalam mengatasi masalah penumpukan perkara di pengadilan dan juga memperkuat dan memaksimalkan fungsi lembaga non-peradilan untuk penyelesaian sengketa di samping proses acara pengadilan yang besifat ajudikatif (memutus). Selain dalam proses mediasi ini harus dituangkan dalam berita acara persidangan, hakim diwajibkan pula untuk menyatakan didalam putusannya bahwa upaya mediasi sudah diusahakan namun tidak berhasil beserta dengan nama hakim yang melakukan mediasi tersebut.

Secara umum Perma tersebut memberi arahan sekaligus peluang bagi Pengadilan Agama, untuk tidak sekonyong-konyong memeriksa dan mengadili setiap sengketa yang masuk, Persoalannya adalah, apakah mediasi yang telah berlangsung selama ini di Pengadilan Agama sudah efektif?. Mediasi yang telah berjalan dalam penyelesaian kasus-kasus diluar sengketa ekonomi syariah telah berjalan dan mediatornya adalah para hakim (sekalipun menurut Perma Nomor 1 Tahun 2003, selain hakim ada beberapa pihak yang juga dapat bertindak sebagai mediator), namun dalam penyelesaian sengketa ekonomi syariah panduan atas Perma Nomor 2 Tahun 2008 tersebut juga belum ada.

Salah satu kendala yang nyata dalam hal dilakukannya mediasi di dalam Pengadilan adalah perihal mediator. Selayaknya, di Pengadilan Agama dibentuk satu unit tersendiri yang khusus menyediakan mediator-mediator (dalam hal ini mediator atas sengketa ekonomi syariah) yang telah bersertifikat (Perma No. 1 Pasal 5 juga mensyaratkan sertifikasi ini). Mediator tersebut sebaiknya bukanlah berasal dari kalangan hakim Pengadilan Agama tetapi dari profesional lain yang telah melalui suatu pendidikan dan sertifikasi untuk menjadi mediator syariah di Pengadilan Agama sebagaimana telah diisyaratkan oleh Perma No. 1. Dalam kenyataannya, menurut Ketua Pusat Mediasi Nasional (PMN) mediator selain hakim yang terdaftar di Pengadilan ternyata tidak efektif di dalam menjalankan tugasnya karena sengketa jika telah masuk ke Pengadilan dan di mediasi maka pilihan selalu diarahkan untuk dimediasi oleh Hakim yang ada. ${ }^{143} 20$

Penyediaan tenaga-tenaga mediator non hakim sangat dimungkinkan. Salah satu alternatif yang dapat dilakukan adalah dengan kerjasamanya Otoritas Jasa Keuangan (OJK) dengan Pusat Mediasi Nasional (PMN). PMN ${ }^{144} 21$ adalah lembaga non profit yang menyediakan pelatihan dan pelayanan dalam bidang mediasi untuk berbagai kasus seperti kasus-kasus dalam bidang hukum, perbankan, tehnik dan bisnis lainnya. Saat ini PMN telah terakreditasi oleh Mahkamah Agung RI untuk periode ketiga yaitu berdasarkan Surat Keputusan Ketua Mahkamah Agung RI No. 136/KMA/SK/VIII/2014 bertanggal 21 Agustus 2014. Berdasarkan akreditasi ini PMN dipercaya oleh Mahkamah Agung untuk memberikan pelatihan dan menerbitkan sertifikasi mediator yang diterima diseluruh Pengadilan tingkat pertama di seluruh Indonesia. Mediator yang telah memiliki sertifikat yang diterbitkan oleh PMN dapat mendaftar pada seluruh pengadilan negeri atau pengadilan agama di seluruh Indonesia untuk menjadi mediator tercatat.

Selain mediator yang disediakan oleh PMN, maka mediator yang ada pada lembaga lain seperti Badan Arbitrase Syariah Nasional (Basyarnas) dan Badan Mediasi Ekonomi Syariah (BaMES) atau lembaga mediasi lain tetap memiliki peluang untuk menyediakan mediatormediator independen yang bertugas di Pengadilan Agama. Putusan atas mediasi yang berupa perjanjian perdamaian harus mendapatkan legalitas dari Pengadilan Agama, dengan demikian penyelesaian sengketa secara cepat dan biaya murah serta memiliki legalitas yang kuat sangat mungkin dapat tercapai. Hal ini tentu akan berdampak pada timbulnya kenyamanan dan kepastian hukum bagi para pelaku bisnis syariah sehingga secara tidak langsung akan mempengaruhi pertumbuhan ekonomi nasional. Hukum dan ekonomi memang tidak dapat dilepaskan. Hubungan antara hukum dan ekonomi sangat erat dan bersifat timbal balik. Hukum

$143{ }^{20}$ Wawancara dengan Fahmi (Ketua PMN) pada September 2015, sebagaimana dikutip dari Renny Supriyatni, B. dan Andy Fariana, Mediasi Syariah Sebagai Alternatif Penyelesaian Sengketa Perbankan Syariah Di Indonesia, (Jakarta: Mitra Wacana Media, 2016)

$144{ }^{21}$ Renny Supriyatni, op.cit. hlm 160. 
mempengaruhi perkembangan ekonomi. ${ }^{145} 22$ Pertumbuhan ekonomi (economic growth) pada suatu Negara menjadi perhatian utama bagi para ekonom dan politikus karena dapat menjadi indikator naik atau turunnya kesejahteraan rakyat. Hal ini sejalan dengan yang diungkapkan di dalam buku economic development, ${ }^{146} 23$ dan hukum menjadi aspek yang sangat penting dalam kontribusi pertumbuhan ekonomi. Hukum mempunyai posisi yang amat penting di dalam upaya untuk menyediakan kondisi yang dapat memacu tumbuhnya pembangunan ekonomi serta untuk menjaga hubungan antar berbagai elemen dan para pelaku ekonomi. ${ }^{147} 24$

Dalam lima tahun terakhir (2009-2013), perekonomian Indonesia mengalami pertumbuhan yang kuat dengan rata-rata pertumbuhan sebesar 5,86 persen. Walaupun setelah itu pertumbuhan ekonomi mengalami pasang surut. Oleh karena itu Pemerintah fokus pada investasi dan konsumsi masyarakat, namun perlu disadari bahwa investasi membutuhkan iklim usaha yang kondusif dan salah satu komponen utamanya ialah kepastian hukum dan keyakinan akan diperolehnya keadilan bagi setiap pencari keadilan. ${ }^{148} 25$ Berdasarkan analisis Kamar Dagang dan Industri (Kadin) pada kuartal I Tahun 2015, pertumbuhan ekonomi melambat sebesar 4,7\% pada tiga bulan pertama 2015, hal ini menggambarkan kondisi yang kurang menguntungkan bagi dunia usaha, dan ini disebabkan permasalahan politik dan hukum. ${ }^{149} 26$

Pertumbuhan ekonomi memang ditunjang banyak faktor dan menyangkut banyak aspek. Salah satu aspeknya adalah pertumbuhan ekonomi syariah yang saat ini masih didominasi oleh sektor keuangan. Aset keuangan syariah pada kuartal III/2014 mencapai sekitar 524 triliun atau sekitar USD 44 miliar dengan saham bank syariah sekitar 49\%, sukuk 39\% lembaga keuangan non bank 8\%. Selain itu ada reksadana syariah, sukuk korporasi. Industri keuangan Islam bervariasi kisaran pertumbuhan dari 10 persen menjadi 30 persen, sedangkan perbankan syariah mencapai 24 persen. Muliaman D. Hadad (OJK) berkeyakinan bahwa pertumbuhan sektor keuangan syariah akan membawa manfaat yang sangat besar bagi fundamental ekonomi nasional kedepan. Hal ini disebabkan karena sektor keuangan syariah yang unik dan berhubungan erat dengan sektor riil, terutama dalam hal pembiayaan yang sangat menghindarkan potensi ekonomi balon dan juga untuk meningkatkan pertumbuhan ekonomi nasional secara signifikan. Selain itu sistem syariah juga menghindarkan sistem spekulasi (gharar) yang membuat sistem tersebut lebih tahan terhadap krisis global sehingga akan membuat stabilitas keuangan yang baik. ${ }^{150} 27$

\section{Kesimpulan dan Rekomendasi}

Mediasi, khususnya mediasi di Pengadilan Agama menjadi Model sebagai solusi penyelesaian sengketa Ekonomi Syariah yang efektif, bila dikaitkan dengan Kompetensi Di Peradilan Agama. Dampak positifnya, dalam Pertumbuhan Ekonomi Nasional sebagai solusi bagi kemungkinan banyaknya kasus dalam bidang ekonomi syariah yang terjadi di masa yang akan datang. Peningkatan investasi yang signifikan di bidang bisnis keuangan syariah dari tahun

$145{ }^{22}$ Abdul Jali, "Peran Hukum dalam Pembangunan ekonomi", Journal of Finance, Volume 2 Nomor (1), . $1-3$

$146{ }^{23}$ Michael P. Todaro and Stephen C. Smith, Economic Development Eleventh Edition, (United Statae: Kendallville, 2011), 14-15

$147{ }^{24}$ Iyan,R.Y., Peran Hukum Dalam Pembangunan Ekonomi, Journal of Finance, 5 (2), $1-15$

$148{ }^{25}$ Editorial media Indonesia, Kepastian Hukum Yang Memacu Pertumbuhan, http://www.media Indonesia. com. (28 Januari 2015)

$149{ }^{26}$ Giran Pasopati, Kadin: kisruh politik \& hukum biang keladi pemburukan ekonomi, http://m.cnnindonesia. com., (11 Mei 2015)

$150{ }^{27}$ Ririn Aprilia, Masa depan industry keuangan syariah, http://news.viva.co.id, 11 November 2014. Agustianto, disampaikan dalam FGD mengenai 'Mediasi sebagai alternative penyelesaian sengketa perbankan syariah”, FH Unpad, Bandung, 1 Desember 2015. Peningkatan investasi yang signifikan di bidang bisnis keuangan syariah dari tahun ke tahun (tercatat ada sekitar $3500 \mathrm{~T}$ ) dan sekitar 1500 transaksi merupakan potensi banyaknya terjadi sengketa, dimana diperlukan mediator-mediator yang dapat memberikan solusi cepat dan biaya murah karena mediasi menawarkan perdamaian dan win-win solution. 
ke tahun (tercatat ada sekitar $3500 \mathrm{~T}$ ) dan sekitar 1500 transaksi merupakan potensi banyaknya terjadi sengketa, dimana diperlukan mediator-mediator yang dapat memberikan solusi cepat dan biaya murah karena mediasi menawarkan perdamaian dan win-win solution. Mediasi didalam pengadilan yang terpisah dari proses persidangan namun mendapatkan legalitas dari hakim Pengadilan Agama akan menjadi salah satu alternatif yang tepat.

Saran yang diberikan, penyelesaian sengketa ekonomi syariah oleh Pengadilan Agama, seharusnya tidak hanya sampai pada tataran kepastian hukum dan diperolehnya keadilan bagi para pencari keadilan tetapi yang lebih luas dari hal tersebut adalah dapat memicu pertumbuhan ekonomi nasional, dan hal ini sangat mungkin dapat dicapai bagi Indonesia yang berdasarkan negaranya pada Pancasila. Selain mengefektifkan lembaga mediasi oleh mediator-mediator independen di dalam Pengadilan Agama, melakukan persidangan secara cepat seperti halnya Pengadilan Niaga yaitu dengan membentuk Pengadilan Niaga Syariah Adhoc, di dalam menyelesaikan kasus kepailitan ekonomi syariah perlu pula menjadi pertimbangan.

\section{Daftar Pustaka}

Abdul Jali. "Peran Hukum dalam Pembangunan ekonomi”. Journal of Finance, 2 (1)

Agustianto, disampaikan dalam FGD. 'Mediasi sebagai alternative penyelesaian sengketa perbankan syariah”. Bandung : FH Unpad, 1 Desember 2015

Andi Syamsu Alam (Ketua Muda Mahkamah Agung Urusan LIngkungan Peradilan Agama) dalam kata Pengantar Buku Hasbi Hasan, berjudul Kompetensi Peradilan Agama, Gramata publishing, 2010.

Bagir Manan. Strategi Pengembangan Peradilan Agama. Makalah dalam seminar tentang Peradilan Agama PPHIM \& Departemen Agama. Jakarta tanggal 8 Desember 1989

Editorial media Indonesia, Kepastian hukum yang memacu pertumbuhan, http://www.media Indonesia.com.

Frank E. Vogel \& Samuel L. Hayes. III (Penterjemah: M. Sobirin Asnawi at. al.). "Hukum Keuangan Islam, Konsep, Teori dan Praktek (Islamic Law and Finance: Religion, Risk, and Return)", Cet. I. Bandung: Nusamedia, 2007.

Giran Pasopati. Kadin: kisruh politik \& hukum biang keladi pemburukan ekonomi. http://m. cnnindonesia.com.

Halim Alamsyah (Deputi Gubernur BI). Perkembangan dan prospek perbankan syariah indonesia, tantangan dalam menyongsong MEA 2015. ceramah ilmiah IAEI, 13 April 2012.

Hasbi Hasan. Kompetensi Peradilan Agama (dalam penyelesaian sengketa ekonomi syariah). Depok: Gramata Publishing, 2010.

Iyan,R.Y. "Peran Hukum Dalam Pembangunan Ekonomi”, Journal of Finance, 5 (2)

Michael P. Todaro and Stephen C. Smith. Economic Development Eleventh Edition. United States: Kendallville, 2011.

Muhammad Tahir Azhari. Negara Hukum Suatu Studi tentang Prinsip Prinsipnya Dilihat Dari Segi Hukum Islam, Implementasinya pada Periode Negara Madinah dan Masa Kini. Jakarta: Bulan Bintang, 1992.

Muhammad Nejatullah Siddiqi. “Teaching Islamic Economics”, Scientific Publishing CentreKing Abdulaziz University. Jeddah, Saudi Arabia, 2005. 
Renny Supriyatni B. Pengantar Perbankan Syariah Di Indonesia. Bandung: Books Terrace \& Library, 2013.

- - - - -, \& Andi Fariana. Mediasi Syariah Sebagai Alternatif Penyelesaian Sengketa Perbankan Syariah Di Indonesia. Jakarta: Mitra Wacana Media, 2016.

Ririn Aprilia. Masa depan industry keuangan syariah. http://news.viva.co.id

Sahetapy, Jacob Elvinus. Runtuhnya Etik Hukum. Jakarta: Penerbit Buku Kompas, 2009.

Sirajuddin. Politik Ketatanegaraan Islam. Jogjakarta: Pustaka Pelajar, 2007.

Soerjono Soekanto. Penelitian Hukum Normatif cetakan 14. Jakarta: Raja Grafindo persada, Jakarta, 2012.

Sufiarina. "The Position and Authority of the Aceh Shari'a Court on the Indonesian Justice System.”Indonesia Law Review 5, no. 2 (27 Juli 2015): 165. doi:10.15742/ilrev.v5n2.105.

Yudo Paripurno, Peran Basyarnas dalam penyelesaian sengketa ekonomi syariah, http:// examinasi.com/2012/01, diakses pada 02 Maret 2012.

Yuslam Fauzi. Seminar Nasional Ekonomi Syariah. Jakarta: ABFII Perbanas, 20 Februari 2012. 